\title{
SANITASI LINGKUNGAN DI KECAMATAN RUNGKUT
}

\section{ENVIRONMENTAL SANITATION IN RUNGKUT DISTRICT}

\author{
Lilis Sulistyorini \\ Fakultas Kesehatan Masyarakat \\ Soenarnatalina Melaniani \\ Fakultas Kesehatan Masyarakat
}

\begin{abstract}
ABSTRAK
Surabaya sebagai ibukota Provinsi Jawa Timur masih memiliki kondisi cakupan rumah yang tidak sehat sebesar $16,54 \%$. Kondisi rumah yang tidak sehat dipengaruhi oleh beberapa hal, antara lain karena faktor pengetahuan maupun karena kondisi lingkungan yang tidak memungkinkan. Kegiatan pengabdian masyarakat berupa pelatihan kepada masyarakat tentang sanitasi lingkungan di Kecamatan Rungkut bertujuan untuk meningkatkan kesadaran penerapan sanitasi lingkungan pada masyarakat. Upaya melatih masyarakat dalam penerapan sanitasi lingkungan di masyarakat dengan kader PKK dan Kepala Keluarga sehingga dapat tercapai kondisi sanitasi lingkungan yang baik serta terpadu di masyarakat. Kegiatan yang dilakukan yakni sosialisasi kepada masyarakat terkait pentingnya menjaga sanitasi lingkungan pada hari pertama serta sosialisasi tentang pembangunan jamban dan septic tank yang sehat pada hari kedua. Hasil kegiatan menunjukkan para peserta kegiatan tampak antusias sepanjang acara, terdapat 3 pertanyaan pada sesi Tanya-Jawab sebagai bentuk antusiasme peserta. Hasil pre-test dan post-test menunjukkan terdapat peningkatan skor peserta. Sosialisasi pembangunan jamban dan septic tank sehat berjalan dengan lancar, beberapa peserta menunjukkan antusiasme untuk membangun jamban dan septic tank dengan menanyakan nomor penyedia kredit jamban. Seminggu setelah sosialisasi dilakukan pembangunan septic tank di rumah salah satu warga yang kurang mampu, dengan dana bantuan dari tim pengabdian masyarakat serta terdapat pula pembangunan septic tank di 3 rumah warga yang tertarik pada saat sosialisasi dilakukan, dengan biaya mandiri. Diharapkan dapat dilakukan kegiatan sejenis di lokasi lain agar sanitasi lingkungan di Surabaya, terutama terkait kepemilikan septic tank di Surabaya dapat lebih baik lagi.
\end{abstract}

Kata kunci: Sanitasi lingkungan, sosialisasi, jamban dan septic tank sehat

\begin{abstract}
Surabaya as the capital of East Java Province still has unhealthy housing coverage conditions of 16.54\%. Unhealthy housing conditions are influenced by several things, including due to knowledge factors or because of environmental conditions that are not possible. Community service activities in the form of training to the community about environmental sanitation in the Rungkut District aims to increase awareness of the application of environmental sanitation to the community. Efforts to train the community in the implementation of environmental sanitation in the community with PKK cadres and family heads so that conditions of good and integrated environmental sanitation can be achieved in the community. The activities carried out were socialization to the community regarding the importance of maintaining environmental sanitation on the first day and socialization of the construction of latrines and healthy septic tanks on the second day. The results of the activity showed the participants were enthusiastic throughout the event, there were 3 questions in the Question and Answer session as a form of enthusiasm of the participants. The results of the pre-test and posttest showed an increase in the score of participants. The socialization of latrine construction and healthy septic tanks went smoothly, some participants showed enthusiasm to build latrines and septic tanks by asking for the number of latrine credit providers. A week after the socialization was carried out the construction of a septic tank in the house of one of the less fortunate residents, with funding from the community service team and the construction of septic tanks in 3 houses of interest at the time of the socialization, at an independent cost. It is expected to be able to do similar activities in other locations so that environmental sanitation in Surabaya, especially regarding the ownership of septic tanks in Surabaya can be even better.
\end{abstract}

Keywords: Environmental sanitation, socialization, latrines and healthy septic tanks 


\section{PENDAHULUAN}

Kesehatan merupakan salah satu aset penting untuk menunjang produktivitas yang optimal dari manusia. Kesehatan seseorang berdasarkan teori HL Belum dipengaruhi oleh berbagai faktor, yaitu: lingkungan, perilaku atau gaya hidup, pelayanan kesehatan, dan keturunan. Lingkungan merupakan faktor terbesar yang menentukan status kesehatan seseorang, diikuti dengan pelayanan kesehatan, faktor perilaku serta keturunan, sehingga diperlukan lingkungan yang sehat, dimulai dari rumah untuk menunjang sehat nya seseorang.

Kumpulan hunian dalam satu wilayah atau disebut dengan kawasan pemukiman, memerlukan prasarana lingkungan pemukiman yang memadai untuk menunjang kehidupan sebagaimana mestinya. Prasarana utama dalam pemukiman meliputi jaringan jalan, jaringan pembuangan air limbah dan sampah, jaringan pemutusan air hujan, jaringan pengadaan air bersih, jaringan telepon, jaringan listrik, jaringan gas, dan lain sebagainya (Keman, 2005).

Kondisi dari lingkungan sekitar hunian memerlukan kondisi yang baik, serta kondisi rumah hunian yang baik pula agar dapat menunjang kehidupan masyarakat yang sehat. Kegiatan untuk menilai kondisi lingkungan yang baik adalah dengan melaksanakan penilaian sanitasi lingkungan. Kondisi perumahan yang sehat dan terkait dengan aspek sanitasi terkait beberapa hal seperti penyediaan air bersih, sanitasi pembuangan sampah, kondisi fisik bangunan, kualitas udara, maupun kondisi lainnya seperti sarana transportasi, seta tersedianya pelayanan sosial.

Kondisi sanitasi lingkungan yang tidak baik dapat menimbulkan berbagai masalah kesehatan. Kondisi yang tidak baik tersebut antara lain adalah menyebabkan diare. Sanitasi dan perilaku kebersihan yang buruk serta air minum yang tidak aman ber kontribusi terhadap 88 persen kematian anak akibat diare di seluruh dunia. Anak-anak yang terpapar diare dan masih bertahan hidup, masalah diare ber kontribusi terhadap masalah gizi. Sehingga menghalangi anak-anak untuk dapat mencapai potensi maksimal mereka. dampak jangka panjang dapat menimbulkan implikasi serius terhadap sumber daya manusia dan kemampuan produktif suatu bangsa di masa yang akan datang (UNICEF Indonesia, 2012).

Sanitasi lingkungan erat kaitannya dengan status rumah sehat. Rumah sehat adalah rumah yang telah memenuhi syarat kesehatan, yakni memiliki jamban sehat, tempat pembuangan sampah, sarana air bersih, sarana pembuangan air limbah, ventilasi baik, kepadatan hunian rumah sesuai dan lantai rumah tidak dari tanah. Badan Lingkungan Hidup Surabaya (2011) menyebutkan permasalahan lingkungan yang dominan di Surabaya pada saat ini terkait dengan masalah populasi dan kepadatan yang terus meningkat, sampah, sanitasi kota, dan kualitas air. Pertambahan penduduk yang sangat tinggi telah melampaui daya dukung lingkungan, sehingga berdampak pada kualitas hidup manusia yang semakin rendah. selain itu masalah persampahan yang ada seperti sampah yang dibuang ke badan sungai atau berserakan di tempat terbuka. Sungai yang tercemar oleh sampah tidak dapat berfungsi sebagaimana mestinya, yakni sebagai fungsi transportasi, konservasi, rekreasi dan sebagainya. Hal ini karena aliran air yang tidak mengalir secara lancar serta rusaknya ekosistem sungai yang diakibatkan oleh zat-zat yang ada dalam sampah tersebut. Lingkungan yang kotor akibat sampah dapat menjadi perindukan berbagai jenis penyakit terutama penyakit yang disebabkan oleh vector dan rodent, seperti nyamuk, lalat, kecoak, dan tikus. Keberadaan vector ini menjadi salah satu indikator seberapa baik kualitas lingkungan suatu kota.

\section{METODE}

Metode pelaksanaan pengabdian masyarakat yang telah tim pengabdian masyarakat terdiri dari beberapa tahapan yaitu:

\section{Bentuk Kegiatan}

Kegiatan berupa penyuluhan dengan pemberian materi melalui media proyektor. Tim melakukan pengukuran pengetahuan dengan mengadakan pretest sebelum pemberian materi dan post tes setelah pemberian materi. Selain itu tim memancing keaktifan peserta dengan memberikan kesempatan apabila ada yang tidak dapat dipahami dengan memberikan pertanyaan atau konsultasi. Bentuk kegiatan secara spesifik diuraikan dalam daftar berikut ini:

1. Pelatihan pelaksanaan sanitasi lingkungan pada kader, dengan menggunakan alat peraga dan ceramah. Pelatihan ini akan diberikan minimal 2 kali selama program.

2. Pelatihan pengenalan sanitasi lingkungan bagi masyarakat Kelurahan Rungkut Kidul, Kecamatan Rungkut, Surabaya. Pelatihan ini berupa ceramah serta pemberian buku saku yang berisi tata cara sanitasi lingkungan, serta pengisian logbook pelaksanaan sanitasi lingkungan selama bulan. Pelatihan akan diberikan minimal 1 kali.

3. Pelaksanaan sanitasi lingkungan pada masyarakat Kelurahan Rungkut Kidul, Kecamatan Rungkut, Surabaya.

\section{Tahapan Pelaksanaan}

Pelaksanaan kegiatan pengabdian masyarakat direncanakan akan dilaksanakan dalam waktu 6 (enam) bulan mulai Juni 2017 hingga Desember 2017.

1. Persiapan (Analisis situasi, rapat persiapan, review budget dan persiapan peralatan \& perlengkapan, cek kesiapan lokasi, penjadwalan, dan lain-lain)

2. Pembuatan buku saku sanitasi dan logbook pelatihan

3. Pelaksanaan ceramah edukasi sanitasi lingkungan masyarakat 
4. Pelatihan sanitasi lingkungan pada masyarakat

5. Pembangunan jamban dan septic tank sehat

\section{Evaluasi Kegiatan}

Evaluasi kegiatan pengabdian kepada masyarakat terdiri dari evaluasi proses dan evaluasi hasil. Evaluasi proses dilakukan pada saat pelaksanaan kegiatan pengabdian kepada masyarakat, sedangkan evaluasi hasil dilakukan setelah kegiatan berlangsung. Partisipasi mitra dalam kegiatan ini merupakan kader PKK yang telah memiliki kemampuan dasar berkomunikasi dengan baik serta akan mengumpulkan data-data kondisi lingkungan masyarakat. kader PKK ini menyediakan tempat pelatihan serta berkontribusi dalam pelaksanaan penilaian sanitasi lingkungan dengan bekerja sama dengan pihak sanitarian puskesmas. Selain itu kader PKK memberikan motivasi kepada masyarakat agar tetap melaksanakan kegiatan sanitasi yang baik di lingkungannya. Kepala keluarga sebagai pembuat kebijakan berpartisipasi sebagai peserta pelatihan jamban dan septic tank sehat dan diharapkan setelah selesai pelatihan dan sosialisasi mempunyai motivasi dalam membuat jamban dan septic tank sehat.

\section{HASIL DAN PEMBAHASAN}

\section{Hasil Pelaksanaan Kegiatan}

Kegiatan pengabdian kepada masyarakat dengan judul "Pelatihan kepada Masyarakat tentang Sanitasi Lingkungan di Kecamatan Rungkut” dilaksanakan di Balai RW 02, Kelurahan Rungkut Kidul, Kecamatan Rungkut, Kota Surabaya. Kegiatan dilakukan pada dua hari, yakni hari Jum'at tanggal 10 November 2017 dan hari Minggu 12 November 2017. Acara pada hari pertama dilaksanakan pada pukul 19.00 WIB dengan peserta berjumlah 16 orang dari 27 orang yang diundang. Target peserta kegiatan ini adalah ibu-ibu pengurus RW 02 Kelurahan Rungkut Kidul.

Kegiatan dimulai dengan penyampaian materi oleh pemateri dengan menggunakan file presentasi menggunakan power point. Topik yang dibahas adalah terkait kegiatan menjaga sanitasi lingkungan pada kehidupan sehari-hari masyarakat. Sebelum acara dimulai, pemateri menyampaikan lembar pretest untuk mengukur seberapa besar ilmu yang diterima oleh peserta setelah pemberian materi. Setelah penyampaian materi, peserta diberikan lembar post test sebagai pembanding jawaban dari pretest yang telah dilakukan. Hasil penilaian pre-test dan post-test menunjukkan terdapat peningkatan rata-rata nilai dari pre-test ke posttest.

Acara pada hari kedua dilaksanakan pada pukul 16.00 WIB, dengan peserta berjumlah 16 orang dari 25 orang yang diundang. Target pelaksanaan kegiatan kedua ini adalah perwakilan KK pada kawasan yang dicurigai tidak memiliki septic tank dan membuangnya langsung pada got kamar mandi menuju saluran pembuangan limbah. Kegiatan dimulai dengan pembukaan oleh Prof. Herry sebagai perwakilan dari LPM Universitas Airlangga, selanjutnya dengan pemberian materi oleh Pak Kun Irianto sebagai konsultan dan pengusaha jamban di Surabaya. Materi yang disampaikan oleh Pak Kun Irianto terkait tentang jamban serta septic tank sehat, serta teknis pembangunan jamban yang dapat diterapkan pada lahan terbatas. Selepas penyampaian materi dilakukan sesi tanya jawab dengan peserta. Kegiatan tanya jawab ini sebagai langkah evaluasi untuk mengukur tingkat pemahaman peserta terkait materi. Pada sesi ini terdapat peserta yang meminta kontak pemateri terkait konsultasi dan pemasangan septic tank. Hal ini menunjukkan adanya antusiasme dan kesadaran peserta untuk memasang septic tank di rumah mereka. Selain itu dilakukan juga kegiatan dokumentasi sebagai bahan laporan kegiatan pengabdian masyarakat.

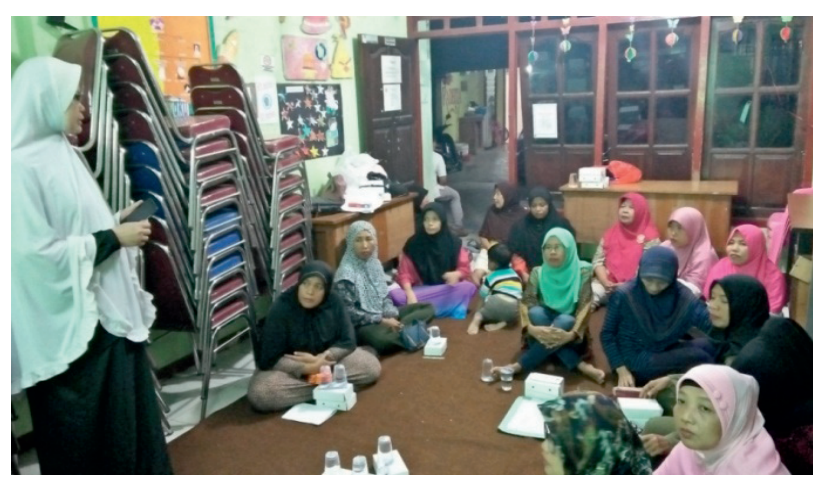

Gambar 1. Pemberian materi mengenai sanitasi lingkungan

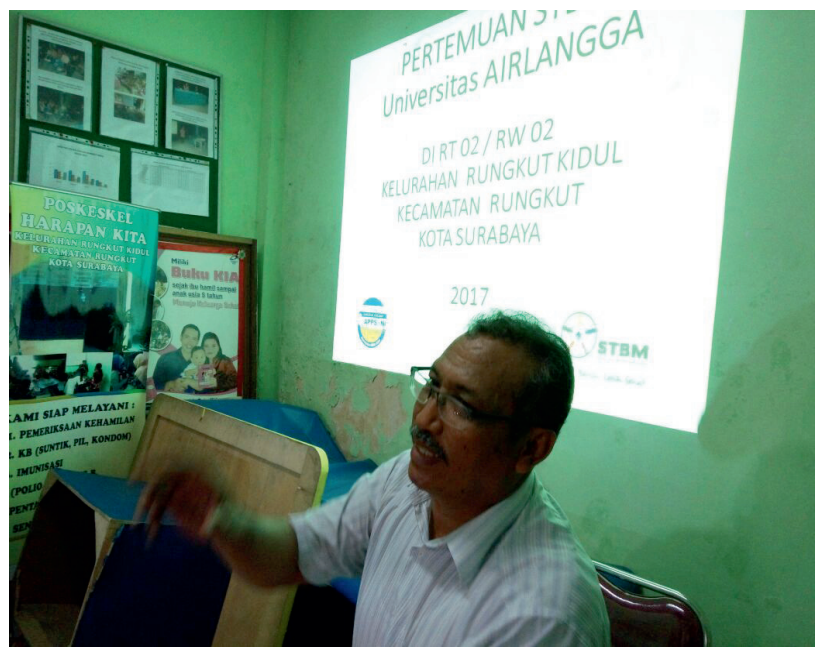

Gambar 2. Pemberian materi mengenai jamban sehat

Setelah kegiatan selesai dilakukan, peserta diberi booklet sanitasi lingkungan, serta terdapat satu perwakilan warga dari RW 2 yang dibantu dibangunkan septic tank. Kriteria pemilihan warga yang dibangunkan septic tank adalah warga yang belum memiliki septic tank serta memiliki kondisi kurang mampu. 
Setelah penyuluhan dilakukan pemberian bantuan pembangunan septic tank kepada $1 \mathrm{KK}$ yang belum memiliki septic tank. Pembangunan septic tank ini dilakukan bekerja sama dengan salah satu pengusaha septic tank yang menjadi narasumber kegiatan penyuluhan sanitasi Lingkungan yang telah dilakukan sebelumnya. Selain itu terdapat pula warga yang membangun septic tank menggunakan biaya sendiri. Pembangunan septic tank dengan biaya sendiri ini pembayarannya dengan sistem mengangsur sebanyak 6 kali ke pengusaha septic tank, sehingga dapat memperingankan warga yang ingin membangun septic tank.

Pembangunan septic tank yang dibantu oleh tim pengabdian masyarakat memakan waktu sebanyak 2 hari. Setelah itu septic tank digunakan dan tidak terdapat kendala selama pemakaiannya. Adapun untuk septic tank yang dibangun dengan biaya sendiri memerlukan waktu pembangunan antara 1,5 sampai dengan 3 hari. $2 \mathrm{KK}$ sudah menggunakan septic tank tersebut, sedangkan $1 \mathrm{KK}$ belum menggunakannya karena belum ada jaringan pipa air bersih yang disebabkan oleh adanya kegiatan renovasi rumah. $2 \mathrm{KK}$ yang telah menggunakan septic tank ini tidak mengalami kendala selama penggunaan septic tank tersebut.

Setelah kegiatan pembangunan, dilakukan kegiatan evaluasi yang dilakukan oleh mahasiswa KKN BBM ke-57 Universitas Airlangga di Kelurahan Rungkut Kidul Surabaya.

\section{Materi Kegiatan}

Pengabdian masyarakat yang telah dilakukan kepada tim pengabdian memberikan beberapa materi yaitu:

Kesehatan merupakan modal utama untuk semua aktivitas, jika kesehatan anak terjaga maka anak dapat melakukan aktivitas sehari-hari dengan baik. Apabila kesehatan suami terjaga, maka dapat bekerja dengan giat untuk keluarga. Begitu pula apabila kesehatan istri terjaga, maka dapat mengurus keluarga, membantu suami maupun bekerja dengan baik. Teori HL Belum menyebutkan bahwa ada 4 faktor yang dapat memengaruhi derajat kesehatan manusia, yakni faktor keturunan, faktor lingkungan, faktor pelayanan kesehatan, dan faktor perilaku. Berdasarkan keempat faktor tersebut, faktor lingkungan merupakan faktor terbesar yang berpengaruh terhadap derajat kesehatan manusia. Lingkungan hidup sendiri berdasarkan UU No. 32 Tahun 2009 terdiri dari semua benda, daya, keadaan, dan mahkluk hidup serta perilakunya yang dapat berpengaruh terhadap perikehidupan dan kesejahteraan manusia serta

\begin{tabular}{lc}
\hline \multicolumn{1}{c}{ Judul Materi } & \multicolumn{1}{c}{ Pemateri } \\
\hline Pelatihan sanitasi lingkungan & Lilis Sulistyorini \\
Pelatihan sanitasi lingkungan tentang & Kun Irianto \\
jamban sehat & \\
\hline
\end{tabular}

makhluk hidup lain. Lingkungan yang tidak dijaga dengan baik akan menimbulkan ketidakseimbangan antar komponen lingkungan yang nantinya juga menimbulkan kerugian bagi makhluk hidup itu sendiri terutama manusia misalnya pencemaran lingkungan dan penyakit menular. Adapun faktor yang cukup berpengaruh terhadap keseimbangan tatanan lingkungan adalah perilaku yang juga merupakan faktor kedua yang dapat memengaruhi derajat kesehatan manusia menurut teori HL Belum. Untuk menjaga keseimbangan komponen lingkungan diperlukan suatu upaya sanitasi lingkungan. Sanitasi lingkungan sendiri menurut WHO adalah upaya pengawasan terhadap beberapa faktor fisik lingkungan yang dapat memengaruhi derajat kesehatan masyarakat.

Pemerintah melalui program Sanitasi Total Berbasis Masya rakat (STBM) melakukan pendekatan dan paradigma baru terhadap pembangunan sanitasi di Indonesia yang mengedepankan pemberdayaan masyarakat dan perubahan perilaku. Salah satu pilar dalam STBM adalah stop Buang Air Besar (BAB) Sembarangan (Kementerian Kesehatan Republik Indonesia 2014). Menurut Permenkes No. 3 Tahun 2014 perilaku buang air besar yang benar dilakukan dengan pemanfaatan sarana sanitasi yang bersifat saniter seperti jamban saniter. Jamban yang saniter sendiri merupakan jamban yang memenuhi standar persyaratan kesehatan yakni:

1. Bangunan atas jamban

Bangunan atas ini seperti atap dan dinding yang berfungsi melindungi pemakai dari berbagai macam gangguan.

2. Bangunan tengah jamban

Bangunan tengah jamban terdiri dari lubang dan lantai jamban. Lubang jamban yang saniter berupa konstruksi leher angsa. Lubang jamban dengan konstruksi leher akan selalu menyisakan air yang berfungsi untuk mengurangi bau. Apabila konstruksi jamban bersifat sederhana dan bukan berjenis leher angsa, sebaiknya diberi tutup di bagian lubangnya. Selain itu terdapat pula lantai jamban yang harus dalam keadaan baik, tidak licin, dan tidak rusak.

3. Bangunan bawah jamban

Bagian bawah jamban terdiri dari bangunan yang berfungsi sebagai penampungan, pengolah, dan pengurai kotoran/tinja yang berfungsi untuk mencegah pencemaran/ kontaminasi lingkungan di sekitarnya oleh vector/rodent pembawa penyakit.

Sementara itu, kondisi fisik jamban harus dalam keadaan baik untuk menunjang kenyamanan bagi pemakainya. Berikut ini merupakan persyaratan jamban yang baik antara lain adalah:

1. Cukup terang

Penerangan yang cukup diperlukan untuk menghindari terjadinya kecelakaan seperti terpeleset dan tersandung. Selain itu penerangan yang cukup diperlukan untuk 
memudahkan pembersihan jamban dan penyiraman kotoran.

2. Cukup ventilasi atau lubang anginnya.

Ventilasi yang baik atau lubang angin berguna untuk menjaga sirkulasi udara tetap lancar sehingga tetap nyaman saat buang air besar. Selain itu, berguna untuk mengurangi bau yang ada di dalam rumah kakus.

3. Tidak menjadi sarang serangga

Serangga merupakan salah satu indikator tidak sehat nya rumah kakus. Usahakan rumah kakus selalu terbebas dari serangga terutama serangga pembawa penyakit seperti kecoa, lalat, nyamuk, dan lain-lain.

4. Selalu dibersihkan

Pembersihan secara rutin penting dilakukan terutama sehabis buang air besar $(\mathrm{BAB})$ harus dibersihkan sampai bersih. Selain untuk menghilangkan bau, pembersihan sampai benar-benar bersih untuk menghargai pengguna jamban selanjutnya.

5. Lubang jamban sekurang-kurangnya 10 meter dari sumber air

Hal ini merupakan persyaratan bagi keluarga yang menggunakan sumur sebagai sumber air bersih. Keberadaan jamban dan septic tank yang $<10$ dari sumber air bersih di takutkan dapat mencemari sumber air bersih dari bakteri dan virus pembawa penyakit.

Adapun dampak buruk yang disebabkan oleh faktor lingkungan antara lain adalah diare yang disebabkan oleh air yang mengandung bakteri, kemudian demam berdarah akibat adanya genangan atau wadah air bersih yang tidak dijaga, kemudian tipus akibat dari lalat yang hinggap di sampah yang dibuang sembarangan, serta akibat dari buang air besar sembarangan misalnya di sungai atau di jamban yang tidak saniter selain dapat mencemari lingkungan juga dapat mengakibatkan berbagai macam penyakit yang diakibatkan sungai yang tercemar tersebut.

\section{Evaluasi Kegiatan}

\section{Evaluasi Proses}

Hari pertama kegiatan terdapat 16 peserta yang datang memenuhi undangan dari 27 orang yang diundang (59,25\%). Peserta yang berhalangan hadir dikarenakan memiliki jadwal kegiatan lain di hari yang sama. Sedangkan hari kedua kegiatan terdapat 16 peserta yang hadir di antara 25 orang yang diundang (64\%). Peserta yang tidak hadir masih cukup banyak karena memang pada hari kegiatan sedang turun hujan. Pada sesi terakhir dari kegiatan, peserta diberi kesempatan untuk mengajukan pertanyaan mengenai materi yang diberikan. Peserta sangat antusias mendengarkan sehingga banyak yang mengajukan pertanyaan.

\section{Evaluasi Hasil}

a. Seperti pada penjelasan sebelumnya, sebelum pemberian materi dimulai, peserta diberi lembar soal pretest untuk mengukur pengetahuan awal peserta tentang jamban dan septic tank. Setelah pemberian materi, peserta kembali dimohon untuk mengisi lembar soal post test untuk mengetahui apakah terdapat penyerapan pengetahuan dari peserta terkait materi yang diberikan. Hasil menunjukkan bahwa terdapat peningkatan pengetahuan peserta mengenai jamban dan septic tank yang baik yang ditandai dengan kenaikan nilai peserta pada soal post test. Peningkatan pengetahuan mengenai jamban dan septic tank sehat ini penting terutama untuk meningkatkan kesadaran untuk menjaga sanitasi lingkungan yang baik mengingat para peserta adalah keluarga yang tidak memiliki jamban dan septic tank sehat dan tokoh yang mempunyai pengaruh di lingkungan masyarakat.

b. Setelah penyuluhan berakhir, ditawarkan kepada warga mengenai pemberian bantuan pembangunan septic tank kepada $1 \mathrm{KK}$ yang belum memiliki jamban dan septic tank. Keluarga yang terpilih untuk mendapatkan bantuan adalah keluarga yang tidak mampu hasil perundingan dengan warga. Proses pembangunan memakan waktu dua hari dan saat ini telah digunakan. Adapun dalam pemakaian septic tank, tidak terdapat kendala yang berarti.

c. Terdapat pula $3 \mathrm{KK}$ yang akan membangun jamban dan septic tank dengan biaya sendiri. Pembayaran dilakukan secara mengangsur sebanyak 6 kali untuk meringankan pengeluaran warga. Hal ini menunjukkan bahwa kesadaran masyarakat akan jamban dan septic tank yang baik meningkat seiring dengan adanya komitmen untuk membuat jamban dan septic tank sehat walau dengan biaya sendiri. Adapun $3 \mathrm{KK}$ tersebut, pembangunan septic tank berkisar antara 1,5 sampai dengan 3 hari. Sebanyak dua KK telah memanfaatkan septic tank sedangkan $1 \mathrm{KK}$ belum memanfaatkan dikarenakan belum ada jaringan pipa air bersih (sedang merenovasi rumah). Dua KK yang telah memanfaatkan septic tank merasa tidak terdapat kendala selama pemanfaatan septic tank tersebut.

\section{KESIMPULAN DAN SARAN}

Hasil evaluasi kegiatan menunjukkan bahwa banyak peserta yang diundang, hadir pada kegiatan pertama maupun kedua. Para peserta kegiatan tampak antusias sepanjang acara, hal ini dibuktikan dengan munculnya beberapa pertanyaan pada sesi Tanya-Jawab sebagai bentuk antusiasme peserta. Untuk mengukur sejauh mana ilmu yang 
disampaikan oleh pemateri diterima oleh peserta kegiatan, dilakukan pre-test dan post-test melalui berbagai pertanyaan oleh pemateri. Hasil pre-test dan post-test menunjukkan terdapat peningkatan skor peserta. Diberikan bantuan berupa pembuatan jamban dan septic tank kepada $1 \mathrm{KK}$ yang tidak mampu. Terdapat pula $3 \mathrm{KK}$ yang berencana melakukan pembangunan jamban dan septic tank dengan biaya sendiri kepada pengusaha dengan angsuran 6 kali untuk meringankan pengeluaran warga. Hal ini menunjukkan adanya kesadaran warga mengenai pentingnya penggunaan jamban dan septic tank sehat dengan berkomitmen untuk membangun jamban dan septic tank sehat dengan biaya sendiri setelah diberikan materi penyuluhan. Pada akhir acara dilakukan kegiatan foto bersama peserta dengan pemateri, serta pemberian bantuan pembangunan septic tank bagi KK yang kurang mampu di RW 02, Kelurahan Rungkut Kidul, Kecamatan Rungkut, Kota Surabaya. Kegiatan sejenis dapat dilakukan di lokasi lain agar sanitasi lingkungan di Surabaya lebih baik.

\section{DAFTAR PUSTAKA}

Badan Lingkungan Hidup Surabaya. 2011. Badan Lingkungan Hidup. [Online] Available at: http://h.surabaya.go.id/ weblh/?c=main\&m=lingperkotaan [Accessed 19 April 2017].

Keman, S. 2005. Kesehatan Perumahan dan Lingkungan Pemukiman. Jurnal Kesehatan Lingkungan, 2(1), pp. 29-42.

Puslitbang Biomedis dan Teknologi Dasar Kesehatan. 2011. Penilaian Air Minum Isi Ulang Berdasarkan Parameter Fisika dan Kimia di dan luar Jabodetabek Tahun 2011. [Online] Available at: http://www.pusat1. litbang.depkes.go.id/index.php/publikasi/jurnal/jurnalkefarmasian-indonesia/95-penilaian-air-minum-isiulang-berdasarkan-parameter-fisika-dan-kimia-didan-luar-jabodetabek-tahun-2011 [Accessed 19 April 2017].

Tim KKN Kelurahan Rungkut Kidul. 2017. Laporan Akhir Pelaksanaan KKN Tematik Cipta Karya Tahun 2017, Surabaya: Lembaga Pengabdian, Pendidikan, Pelatihan, dan Pengembangan Masyarakat (LP4M) Universitas Airlangga.

UNICEF Indonesia. 2012. UNICEF. [Online] Available at: https://www.unicef.org/indonesia/id/A8_-_B Ringkasan_Kajian_Air_Bersih.pdf [Accessed $19 \overline{\text { April }}$ 2017]. 